\title{
ARCHEAN ACCRETION IN THE SÃO JOSÉ DO CAMPESTRE MASSIF, BORBOREMA PROVINCE, NORTHEAST BRAZIL
}

\author{
ELTON LUIZ DANTAS $* * * * *$, PETER CHRISTIAN HACKSPACHER*, WILLIAM RANDALL VAN SCHMUS AND \\ BENJAMIN BLEY DE BRITO NEVES****
}

\begin{abstract}
Preliminary U-Pb and Sm-Nd geochronological results from the Sao José do Campestre (formerly Caldas Bandao) Massif (SJCM) in the Borborema Province of NE Brazil show evidence for three distinct stages of Archean petrogenesis. The first stage occurred at $3.45 \mathrm{Ga}$ and involved reworking of a slightly older, primitive crust. The second stage took place at $3.2 \mathrm{Ga}$ (Mesoarchean) and is marked by the generation of juvenile crust, with a large production of trondhemitic rocks. The latest magmatic event occurred about $2.7 \mathrm{Ga}$ (Neo-Archean) and produced alkali-rich magmas. Recognition of these different Archean events involving accretion of continental crust into a older cratonic nuclei is an important contribution to the knowledge of the regional tectonic history of the Borborema
\end{abstract} Province in particular and Gondwana in general.

Keywords: Archean crust; $\mathrm{U} / \mathrm{Pb}$ and $\mathrm{Sm} / \mathrm{Nd}$ geochronology; juvenile and reworked crust; Borborema Province; Brazil Precambrian.

RESUMO ACRECAO ARQUEANA NO MACIÇO SÃO JOSÉ DO CAMPESTRE, PROVINCIA BORBOREMA, NORDESTE DO BRASIL Resultados preliminares obtidos atraves de geocronologia U/Pb e $\mathrm{Sm} / \mathrm{Nd}$ para o Macico Sao José do Campestre mostra evidbncias de tres diferentes fases de petrogenese Arqueana. A primeira fase ocorreu em torno de 3,45 Ga e envolve retrabalhamento de uma antiga crosta primitiva. A segunda fase desenvolveu-se durante o Meso-Arqueano (3,2 Ga) e e caracterizada pela formação de crosta juvenil e grande geração de rochas trondhjemfticas. $\mathrm{O}$ ultimo evento de magmatismo ocorreu ao redor de $2,7 \mathrm{Ga}$ (durante o Neo-Arqueano) é representado por magmas ricos em alcalis. Estes diferentes eventos de acrecão de crosta continental no Arqueano são uma relevante contribuifao para o conhecimento da histdria tectonica regional da Provincia Borborema.

Palavras chaves.: Crosta Arqueana; geocronologia U/Pb e $\mathrm{Sm} / \mathrm{Nd}$; crosta juvenil e retrabalhada; Provincia Borborema.

INTRODUCTION The Sao Jose do Campestre Massif (SJCM) is a geotectonic unit located in the NE part of the Borborema Province, northeastern Brazil. The SJCM was originally defined as the Caldas Brandao Massif (CBM; Brito Neves, 1975), based on several $\mathrm{Rb}-\mathrm{Sr}$ and K-Ar ages reflecting a complex evolution, with the basement rocks yielding $\mathrm{Rb}-\mathrm{Sr}$ ages range from 2.7 (Archean) to $2.1 \mathrm{Ga}$ (early Paleoproterozoic). We have changed the designation here to Sao Jose do Campestre Massif because basement in the vicinity of Caldas Brandao is now known to be part of a separate geotectonic block (Brito Neves, pers. comm., 1998). The SJCM is composed dominantly of these basement domains, which were subsequently deformed, metamorphosed, and intruded by granitoids during the 600 Ma Brasiliano Orogeny.

Using $\mathrm{U} / \mathrm{Pb}$ and $\mathrm{Sm} / \mathrm{Nd}$ geochronology, Van Schmus et al. (1995) and Dantas et al. (1995) recognized an Archean nuclei older than $3.2 \mathrm{Ga}$ in the basement complex of the SJCM (then referred to as $\mathrm{CBM}$ ). These results showed that Archean units in the Borborema Province were less abundant, but had a more complex history, than previously was supposed. The Archean block is surrounded by Paleoproterozoic terranes and comprises an area of aproximatly $6000 \mathrm{~km}^{2}$ that is exposed between the cities of Bom Jesus and Sao Jose do Campestre, 70 $\mathrm{km}$ from Natal, State of Rio Grande do Norte (Figure 1).

In the present paper, we describe the general characteristics of Archean assemblages found in this region, report $\mathrm{U} / \mathrm{Pb}$ and $\mathrm{Sm} / \mathrm{Nd}$ data from selected units, and discuss the interpretation of these data within the geological framework of the Borborema Province. The application of $\mathrm{U}-\mathrm{Pb}$ geochronology in this area permits accurate determination of the crystallization ages of different assemblages found in the SJCM, while the Sm-Nd data aid in interpretation of the crustal history for this region (i. e., periods of continental crust formation).
GEOLOGIC FRAMEWORK The Sao Jose do Campestre Massif (SJCM) was originally defined by Brito Neves $(1975,1983)$ as a unit (originally called Caldas Brandao Massif) within the Borborema Province. It is a basement block (or median massif), composed mainly of migmatites and anatectic gneiss complexes yielding a $2.7 \mathrm{Ga} \mathrm{Rb}-\mathrm{Sr}$ age. These rocks were reworked during the Trans-Amazonian and Brasiliano Orogenesis at $2.2 \mathrm{Ga}$ and $600 \mathrm{Ma}$, respectively, characterizing their polycyclical (deformation, metamorphism, and magmatism) evolution. The regional geology of this section of the Borborema Province includes faultbounded metasedimentary belts within the high grade gneissic basement (i.e.; Serido Group) and intrusive Brasiliano granitoids. Strike slip shear zones of Brasiliano age (Brito Neves, 1983; Jardim de Sa, 1994; Vauchez et al.,1995) are the most important structural features observed throughout the Borborema Province and are responsible for defining its final configuration at the end of the Neoproterozoic.

The presence of rocks older than $3.2 \mathrm{Ga}$ was suggested by Sm-Nd model ages (Van Schmus et al, 1995) and encouraged us to carry out a geologic mapping at 1:250,000 scale of the Archean nucleus present in the SJCM. The Archean nucleus is characterized by the presence of different rock units. Field relationships between each of these units shows petrographic, structural, and textural characteristics from which different phases of Archean petrogenesis are revealed.

The most representative Archean assemblage in the SJCM includes grey gneisses of trondhjemitic, tonalitic, and granodioritic compositions (a TTG suite). The tonalitic orthogneiss is comprised of plagioclase, hornblende, biotite, and quartz; zircon, apatite, and allanite occur as acessory minerals. A mafic gneiss containing amphibolitic rocks (dykes, inclusions, and enclaves) is also abundant. These assemblages occur mainly in the region between the cities of Bom Jesus

* DPM/IGCE/UNESP, P.O.Box 178, 13506-900, Rio Claro-SP-Brazil; e-mail: eltonld@caviar.igce.unesp.br; phack@caviar.igce.unesp.br

** Dept. of Geology, University of Kansas, Lawrence, KS 66045 USA; e-mail: rvschmus@kuhub.cc.ukans.edu

*** IG/USP, P. O. Box 11348, 05422-970, Sao Paulo-SP, Brazil. E-mail: bbleybn@usp.br 


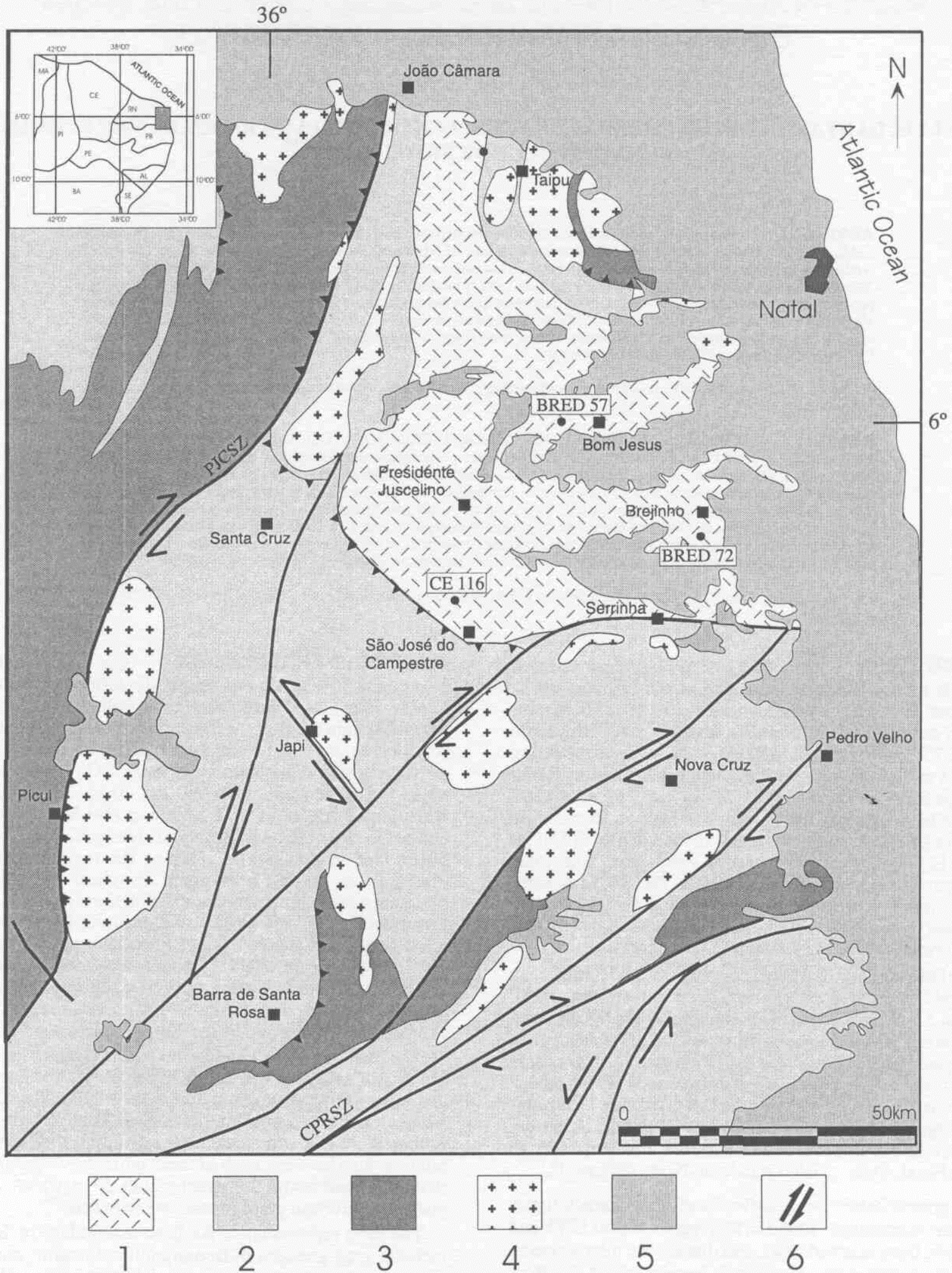

Figure 1 - Simplified geologic map of São José Campestre Massif, Borborema Province (Almeida et al, 1977; Brito Neves, 1975,1983 ; Jardim de Sá, 1984). The Archean block (1) Paleoproterozoic (2) andNeoproterozoic (3) units, Brasiliano granites (4) and Phanerozoic cover (5) are also showed. The dots represents the U-Pb sample localities and the squares represent the cities. PJCSZ-Picui-Joao Camara shear zone; CPRSZ-Cacerengo-Poçinho-Remígio shear zone (6).

Figura 1 - Mapa geológico simplificado do Macico São José do Campestre, Província Borborema (Almeida et al., 1977; Brito Neves, 1975,1983 ; Jardim de Sá, 1984) delimitando o bloco Arqueano das unidades Paleoproterozoicas (2) e Neoproterozoicas (3). Granites Brasilianos e a cobertura Fanerozoica tambem sao mostrados. As amostradas analisadas estao representadas como pontos e as principais cidades da regiao, como quadrados. PJCSZ- zona de cisalhamento de Picui-Joao Camara; CPRSZ- zona de cisalhamento de Cacerengo-Pocinho-Remígio (6). 
and Presidente Juscelino (see Figure 1). These rocks display recumbent and isoclinal folds and are intensely migmatized.

Another phase of magmatism mapped in the SJCM is composed mainly of a second phase of trondhjemitic to granitic grey gneisses, which occur in the Brejinho region near the boundary of the Archean nucleus and adjacent Paleoproterozoic terranes. The trondhjemitic to granitic gneisses are characterized by garnet-bearing gneisses; they generally cut across some of the mafic gneisses described above and are highly deformed and migmatized. The leucosomes formed in the migmatites preferentially appear to have been injected in strike-slip shear zones and/or occur in situ, associated with open folds. The leucosomes are predominantly equigranular, leucocratic rocks of trondhjemitic composition.

The youngest magmatic phase is represented by a pluton of syenogranite that occurs $10 \mathrm{~km}$ north of São José do Campestre. This pluton forms an elongate body around the border of the Archean nucleus. The syenogranite is a coarsegrained rock composed of microcline, quartz, hornblende, and rare clinopyroxene, together with allanite, as essential minerals.

Thus, the SJCM should be considered as one small Archean nucleus complex that occurs in the Borborema Province of northeastern Brazil and is surrounded by early Paleoproterozoic terranes. The Archean nucleus includes several lithologic assemblages that reveal three distinct phases of Archean petrogenesis. In order to define a precise chronostratigraphy for these units, we obtained U-Pb zircon crystallization ages and Sm-Nd crustal formation ages from representative samples of each phase to place time limits on each magmatic event in the nucleus.

ANALYTICAL METHODS Analytical data (Table 1 and 2) were obtained at the Isotope Geochemistry Laboratory (IGL), Department of Geology and Kansas University Center for Research, University of Kansas. Zircons were dissolved and $\mathrm{Pb}$ and $\mathrm{U}$ were separated using procedures modified after Krogh $(1973,1982)$ and Parrish (1987). Relatively small zircons and single crystal analyses samples were total-spiked with a mixed ${ }^{205} \mathrm{pb}^{235} \mathrm{U}$ tracer solution. Isotopic ratios were measured in a static mode using a VG Sector multi-collector mass spectrometer equiped with a Daly detector for large samples. Small samples were measured in single-collector mode using the Daly detector. $\mathrm{Pb}$ isotopic compositions were analysed on single Re filaments using silica gel and phosphoric acid and corrected for average mass discrimination of 0.12 \pm 0.05 percent per mass unit, which was determined by analysis of NBS SRM-982 (equal-atom Pb) and monitored by analysis of NBS SRM-983 (radiogenic Pb). In most cases uranium was loaded on a single Re filament with phosphoric acid and a layer of colloidal carbon and analysed as $\mathrm{U}^{+}$. In some single crystal analyses, as noted below, the dissolved sample was loaded with phosphoric acid and silica gel on a single Re filament and measured in the mass spectrometer without ion exchange columm purification; in these cases the uranium was analysed as $\mathrm{Uo}_{2}$. Uranium fractionation was monitored by analyses of NBS SRM U-500. Uncertainties in $\mathrm{U} / \mathrm{Pb}$ ratios due to uncertainties in fractionation and mass spectrometer for typical analyses are $\pm 0.5 \%$; in some instances weak signals (e.g. single crystals) caused uncertainties of $\pm 2 \%$. Radiogenic ${ }^{208} \mathrm{~Pb},{ }^{207} \mathrm{~Pb}$, and ${ }^{206} \mathrm{~Pb}$ were calculated by correcting for modern blank $\mathrm{Pb}$ and for nonradiogenic original $\mathrm{Pb}$ corresponding to Stacey and Kramers (1975) model $\mathrm{Pb}$ for the approximate age of the sample. Uncertainties in radiogenic $\mathrm{Pb}$ ratios are typically $\pm 0.1 \%$ unless the sample had an unusually low ${ }^{206} \mathrm{~Pb} /{ }^{204} \mathrm{~Pb}$ ratio, in which case uncertainties in the common $\mathrm{Pb}$ correction could cause greater uncertainties. Decay constants used were $0.155125 \times 10^{-9}$ year ${ }^{-1}$ for ${ }^{238} \mathrm{U}$ and $0.98485 \times 10^{-9}$ year ${ }^{\text {for }}{ }^{235} \mathrm{U}$. Blanks ranged from ca. 100 to $10 \mathrm{pg}$ total $\mathrm{Pb}$ over the past few years depending on the dissolution procedure used and improvements in the IGL clean-lab; in most cases they do not contribute significantly to uncertainties in the ages of samples, although some of the single-crystal analyses may show the effects of blank $\mathrm{Pb}$ as larger uncertainties in the calculated ages. Zircon data (Table 1) were regressed using the ISOPLOT program of Ludwing (1993). Model 1 regressions were accepted if probabilities of fit were better than 30 percent; Model 2 regressions were used if probabilities of fit were less than 30 percent. Uncertainties in concordia intercept ages are given at the 2-sigma level.

Rock powders for $\mathrm{Sm} / \mathrm{Nd}$ analysis were dissolved and the REE were extracted using the standard methods of Patchet and Ruiz (1987). Isotopic compositions were measured with a VGA Sector multi-colletor mass spectrometer. Sm was loaded with $\mathrm{H}_{3} \mathrm{PO}_{4}$ on a single Ta filament and typically analysed as $\mathrm{Sm}^{+}$in static multicollector mode. Nd was loaded with phosphoric acid on a single Re filament having a thin layer of AGW-50 resin beads and analysed as $\mathrm{Nd}^{+}$using dynamic mode. External precision based on repeated analyses of our internal standard is \pm 20 ppm (1 sigma) or better. All analyses are adjusted for instrumental bias determined by measurements of our internal standard for periodic adjustment of collector positions. On this basis our analyses of La Jolla $\mathrm{Nd}$ average $0.511860 \pm 0.000010$. Eight analyses of BCR-1 yielded $\mathrm{Nd}=29.44 \pm 0.70 \mathrm{ppm}, \mathrm{Sm}=6.77 \pm 0.21 \mathrm{ppm}$, $0.512641 \pm 0.000007$, yielding $\mathrm{eNd}(0)=0.07 \pm 0.12$ (all at 1 sigma). $\mathrm{Sm} / \mathrm{Nd}$ ratios are correct to within \pm 0.5 percent, based on analytical uncertainties; $\mathrm{eNd}(\mathrm{t})$ values were calculated using either the U-Pb ages defined from zircons where available (Table 2) or estimated ages based on the regional geology and unpublished results from nearby samples. $\mathrm{T}_{\mathrm{DM}}$ ages were calculated using the model of DePaolo (1981) and are also given in Table 2 .

RESULTS Three representative samples of the Archean nucleus in the SJCM were selected for geocronologic studies based on field relationships. These samples are representative of the lithologic diversity observed in the area. In the Figure 1 we shows the sample locations, main cities described in the text, and the main geologic regional units in the SJCM.

Tonalite Gneiss of Bom Jesus The ubiquitous tonalitic grey gneiss located $10 \mathrm{~km}$ west of the town of Bom Jesus (Sample BRED-57) yielded the oldest ages among the selected samples, consistent with its relative age as infered from field evidence (Figure $2 \mathrm{a}$ ).

Two zircon populations are present in these rocks (Figure 2b). All zircons analysed were submitted to air abrasion (Krogh, 1973) and were analysed as single grains (Table 1). The first population of zircons is characterized by brown to black, long, primatic, zircons with high $\mathrm{U}$ and $\mathrm{Pb}$ concentrations. We analysed six fractions, which do not plot along a single discordia; a bulk regression yields an age of $3481 \pm 123$ Ma, but this should not be taken as the best estimate of the age. A minimum age is obtained when we consider the two most concordant zircon fractions (fractions 7 and 8), which yield a $3396+/-8$ Ma upper intercept and a $623 \pm 8$ Ma lower intercept. The oldest estimate of the age is given by fractions 3 and 7, which yield an age of $3446+/-5$ Ma with a lower intercept of $1053 \pm 15$ Ma. Other combinations (Figure 2c) yield intermediate ages. Thus, it appears that this rock originally formed at least $3.40 \mathrm{Ga}$ and may be $3.45 \mathrm{Ma}$ or older. This age around $3.4 \mathrm{Ga}$ is interpreted as the crystallization age of the protolith to the Bom Jesus tonalite gneiss. The apparent ages defined by the lower intercept are attribued to a complex history of $\mathrm{Pb}$ loss and cannot be used to define younger events. 
Table 1 - U-Pb results for the Archean rocks of the SJCM, Northeastern Brazil.

Tabela 1 - Resultados U/Pb de rochas arqueanas do SJCM, Nordeste do Brasil.

\begin{tabular}{|c|c|c|c|c|c|c|c|c|c|c|}
\hline \multirow{3}{*}{ Fraction 1} & \multirow{3}{*}{$\begin{array}{l}\text { Size } \\
\text { (mg) }\end{array}$} & \multicolumn{2}{|c|}{ Concentrations ${ }^{2}$} & \multirow{3}{*}{$\begin{array}{c}\text { Observed }^{3} \\
206 \mathrm{~Pb} \\
204 \mathrm{~Pb}\end{array}$} & \multicolumn{3}{|c|}{ Atomic Ratios 4} & \multicolumn{3}{|c|}{ Ages $(\mathrm{Ma})^{5}$} \\
\hline & & $\mathbf{U}$ & $\mathrm{Pb}$ & & $206 \mathrm{~Pb}$ & ${ }^{207} \mathrm{~Pb}$ & ${ }^{207} \mathrm{~Pb}$ & $206 \mathrm{~Pb}$ & $207 \mathrm{~Pb}$ & $207 \mathrm{~Pb} \quad \pm$ \\
\hline & & $(\mathrm{ppm})$ & (pprn) & & $238 \mathrm{U}$ & $235_{U}$ & ${ }^{206} \mathrm{~Pb}$ & $238 \mathrm{U}$ & $235 \mathrm{U}$ & $206 \mathrm{~Pb} \quad 1 \sigma$ \\
\hline \multicolumn{11}{|l|}{ BRED-57 } \\
\hline 5: NM(-2),s & 0.026 & 61 & 34 & 1,386 & 0.46396 & 15.8112 & 0.24716 & 2,457 & 2,865 & $3,167 \pm 01$ \\
\hline 4: NM(-1)L,s & 0.036 & 2290 & 1160 & 46,781 & 0.47036 & 15.7211 & 0.24209 & 2,485 & 2,860 & $3,136 \pm 01$ \\
\hline 3: M(-1)L,s & 0.084 & 568 & 262 & 18,122 & 0.41469 & 13.9047 & 0.24318 & 2,236 & 2,743 & $3,141 \pm 0 \mathrm{l}$ \\
\hline 8: M(0)L,s & 0.040 & 754 & 538 & 6.736 & 0.63736 & 24.8331 & 0.28258 & 3,179 & 3,302 & $3,377 \pm 03$ \\
\hline $7: M(0) L, s$ & 0.021 & 1210 & 778 & 6,936 & 0.57055 & 21.8429 & 0.27766 & 2,910 & 3,177 & $3,350 \div 01$ \\
\hline $6: M(0) L, s$ & 0.018 & 2859 & 1547 & 7,854 & 0.50051 & 15.7645 & 0.22844 & 2,616 & 2,862 & $3,041 \pm 01$ \\
\hline $2: \mathrm{M}(0) \mathrm{L}, \mathrm{s}$ & 0.024 & 2651 & 727 & 17,872 & 0.28222 & 4.7962 & 0.12326 & 1,603 & 1,784 & $2,004 \pm 04$ \\
\hline 1: M(1)S,s & 0.020 & 500 & 198 & 6,897 & 0.35479 & 6.04261 & $0.123 \$ 2$ & 1,957 & 1,982 & $2,008 \pm 02$ \\
\hline \multicolumn{11}{|l|}{ BRED-72 } \\
\hline $\mathrm{NM}(-1) \mathrm{E}, \mathrm{sn}$ & 0.040 & 126 & 90 & 2,995 & 0.59458 & 19.9579 & 0.24345 & 3,008 & 3,089 & $3,143 \pm 02$ \\
\hline$M(0) E, m$ & 0.063 & 143 & 100 & 4,571 & 0.57984 & 19.3109 & 0.24154 & 2,948 & 3,057 & $3,130 \pm 03$ \\
\hline \multicolumn{11}{|l|}{ CE-116 } \\
\hline$\overline{M(-1) E}, m$ & 0.686 & 357 & 168 & 83,888 & 0.42159 & 10.2243 & 0.17589 & 2,268 & 2,455 & $2,615 \pm 01$ \\
\hline $\mathrm{M}(1) \mathrm{L}, \mathrm{m}$ & 0.047 & 185 & 79 & 7,414 & 0.38478 & 9.1352 & 0.17219 & 2,099 & 2,352 & $2,579 \pm 01$ \\
\hline$M(1) S, m$ & 0.049 & 322 & 172 & 14.684 & 0.47146 & 11.7333 & 0.18050 & 2,490 & 2,583 & $2,658 \pm 01$ \\
\hline$M(0) S, m$ & 0.048 & 365 & 190 & 15,314 & 0.46720 & 11.5745 & 0.17968 & 2,471 & 2,571 & $2,650 \pm 01$ \\
\hline$M(-1) S, m$ & 0.086 & 456 & 245 & 15,080 & 0.47605 & 11.8552 & 0.18061 & 2,510 & 2,593 & $2,659 \pm 01$ \\
\hline $\mathrm{M}(0) \mathrm{L}, \mathrm{m}$ & 0.086 & 200 & 103 & 6,285 & 0.45142 & 11.1639 & 0.17936 & 2,401 & 2,537 & $2,647 \pm 02$ \\
\hline
\end{tabular}

1: $\mathrm{NM}=$ nonmagnetic, $\mathrm{M}=$ magnetic, numbers in parentheses indicate side tilt used on Franz separator at 1.5 amp power; $\mathrm{E}=$ hand-picked elongate to euhedral grains; $\mathrm{L}=$ elongate grains; $\mathrm{S}=$ stubby; $\mathrm{s}=$ single grain; $\mathrm{m}=$ multiple grains. First number $=$ ID\# on Figure 4.3 of Elton's thesis

2. Total $\mathrm{U}$ and $\mathrm{Pb}$ concentrations corrected for analytical blank.

3: Not corrected for blank or non-radiogenic $\mathrm{Pb}$.

4: Radiogenic $\mathrm{Pb}$ corrected for blank and initial $\mathrm{Pb}$; $\mathrm{U}$ corrected for blank

5: Ages given in Ma using decay constants recommended by Steiger and Jager (1977).

Table 2 - Sm-Nd Results for the Archean rocks of the SJCM, Northeastern Brazil

Tabela 2 - Resultados Sm/Nd de rochas arqueanas do SJCM, Nordeste do Brasil.

\begin{tabular}{|lccccccccc|}
\hline Sample ID & $\begin{array}{c}\mathrm{Nd} \\
\mathrm{ppm}\end{array}$ & $\begin{array}{c}\mathrm{Sm} \\
\mathrm{ppm}\end{array}$ & $\begin{array}{c}147 \mathrm{Sm} \\
144 \mathrm{Nd}\end{array}$ & $\begin{array}{c}143 \mathrm{Nd} \\
144 \mathrm{Nd}\end{array}$ & $\pm 2 \sigma$ & $\begin{array}{c}\mathrm{E}(\mathrm{Nd}) \\
(\text { today })\end{array}$ & $\begin{array}{c}\text { (t) } \\
\mathrm{Ga}\end{array}$ & $\begin{array}{c}\mathrm{E}(\mathrm{Nd}) \\
(\mathrm{t})\end{array}$ & $\begin{array}{c}\mathrm{T}(\mathrm{DM}) \\
\mathrm{Ga}\end{array}$ \\
\hline BRED-57 & 34.62 & 7.11 & 0.12423 & 0.510890 & \pm 10 & -34.1 & 3.45 & -1.86 & 3.73 \\
BRED-72 & 63.85 & 16.88 & 0.15987 & 0.511926 & \pm 09 & -13.9 & 3.18 & 1.22 & 3.22 \\
CE-116 & 118.84 & 21.16 & 0.10766 & 0.510842 & \pm 13 & -35.0 & 2.69 & -4.2 & 3.18 \\
\hline
\end{tabular}

The second zircon population present in the Bom Jesus Tonalite gneiss, represented by fractions 1 and 2, shows a short, stubby, prismatic morphology of uncolored, clear, zircon. These fractions yield a nearly concordant age around 2.0 $\mathrm{Ga}$ (Figure $2 \mathrm{~b}$ and $2 \mathrm{~d}$ ). These grains are interpreted as metamorphic zircons formed during latter stages of Transamazonian high-grade metamorphism. Supporting this hypothesis, these zircon have low $\mathrm{Th} / \mathrm{U}$ ratios, similar to those described by several authors (Toteu et al., 1990; Williams, 1992; Corfu, 1996; Mezger \& Krogstad, 1997). If we assume a two-stage history (Geauter \& Grunenfelder, 1979) to explain the behavoir of the zircons present in the Bom Jesus tonalite gneiss, we can pass a discordia through $2.0 \mathrm{Ga}$ (metamorphism age) and some of the more concordant fractions from the first population to obtain a maximum age of $3.5 \mathrm{Ga}$ (protolith age or age of inherited xenocrysts from older continental crust). Possible episodic $\mathrm{Pb}$ loss around $600 \mathrm{Ma}$, representing reworking during the Brasiliano event, could be represented by some of the apparent lower intercepts, explaining the intermediate position of some zircons fractions in the discordia diagram (Figure 2e). Deformation alone will not reset the zircons. You also need temperature (granulite facies if dry, lower if wet) to do it.

For the present, we prefer the interpretation that Archean rocks $(3.4 \mathrm{Ga})$ of Bom Jesus were strongly overprinted by a 2.0 deformational and thermal event, and possibly also by the 600 Ma Brasiliano event, generating locally complex isotopic behaviour of zircons populations in this sample.

The Sm-Nd geochronology is represented as TDM model age and by Epsilon $\left(\mathrm{e}_{\mathrm{Nd}}\right)$ values showed in the Figure 3. For the same rock analyzed by U-Pb geochronology (sample BRED-57), a Sm/Nd TDM model age of $3.77 \mathrm{Ga}$, with $\mathrm{e}_{\mathrm{Nd}}(0)$ values very negative and a $\mathrm{e}_{\mathrm{Nd}(\mathrm{t})}(@ 3.45 \mathrm{Ga})$ of -1.4 was obtained. These data suggest that the orthogneiss of Bom Jesus region was formed about $3.7 \mathrm{Ga}$ from an older reworked crust or from an enriched mantle at $3.45 \mathrm{Ga}$. 

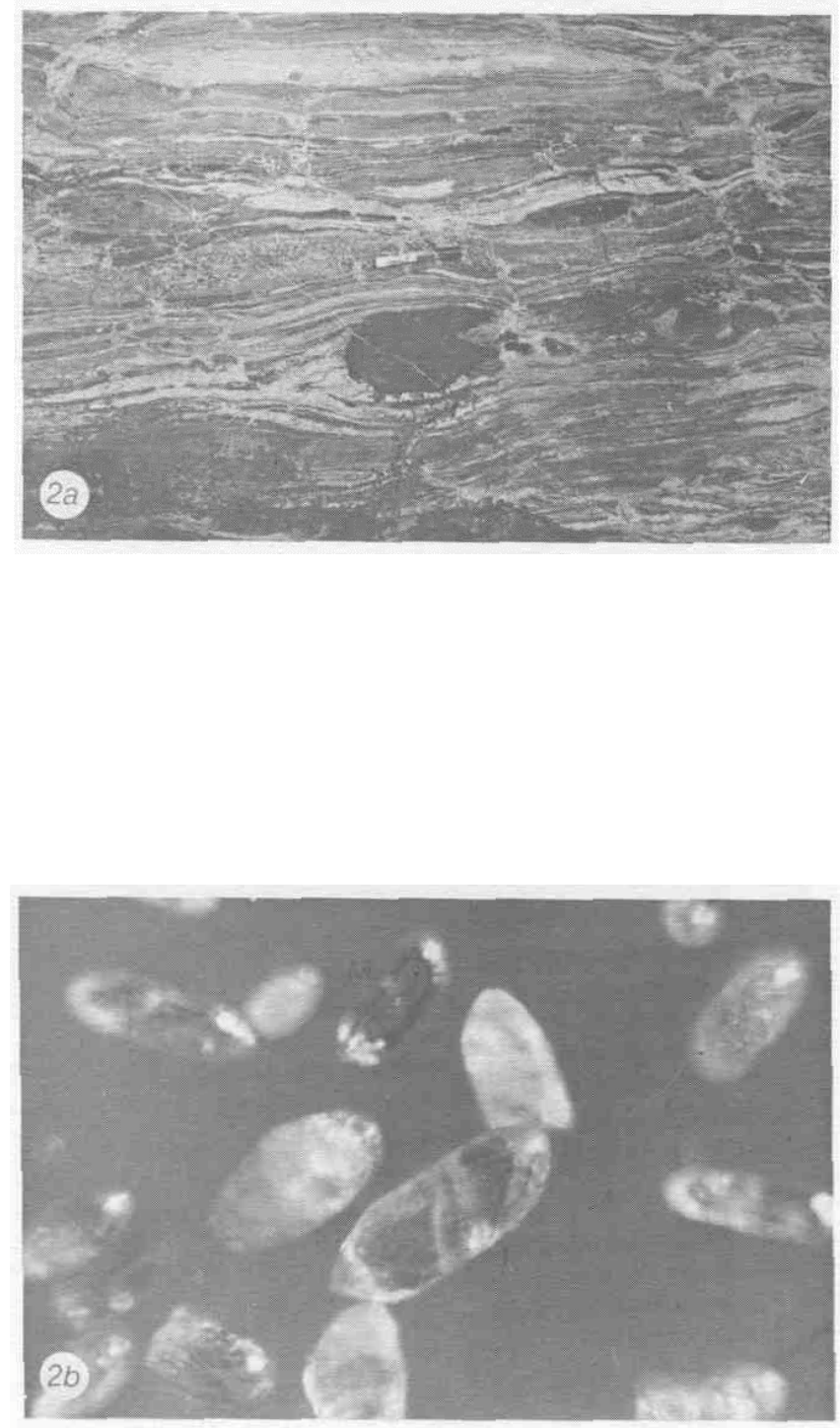
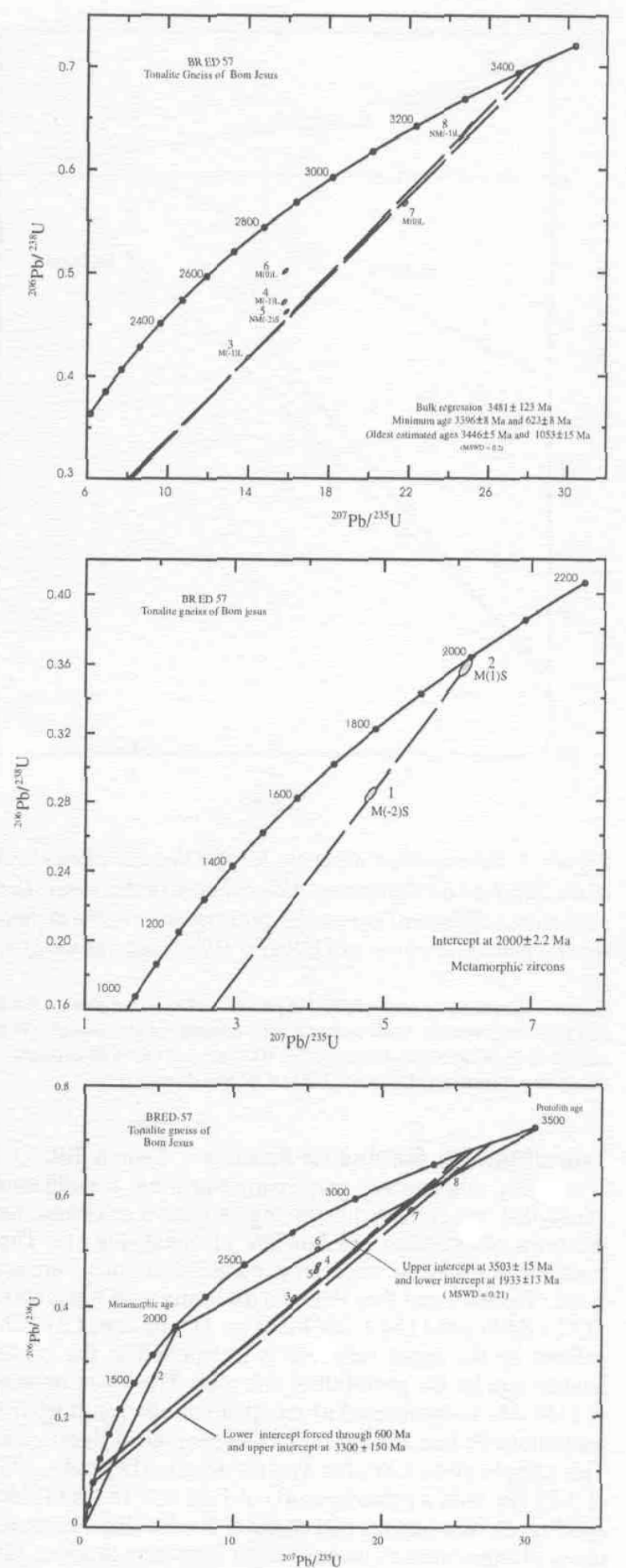

Figure 2. (a) Field aspect of dated rock showing the banded foliation

and amphibolite enclaves, (b) Microphotography showing two different zircon populations founded in the Bom Jesus tonalite gneiss. I - igneous; $M=$ metamorphic; Photomicrography shows $10 X$ enlargement, (c) Concordia diagram for tonalitic gneiss of the Bom Jesus region. Bulk regression using six zircon fractions define a $3.45 \mathrm{Ga}$ crystallization age. Different estimated ages are showed (see text for details). M- magnetic and NM- nonmagnetic susceptibility fractions, (d) Concordia diagram for metamorphic zircons, (e) Interpretation of a two stage evolutive history for zircons present in the Archean gneiss of Bom Jesus region considering a metamorphism event during the Transamazonian and rewoking during the Brasiliano thermal event. Figura 2. (a) Aspecto de campo da rocha datada mostrando a foliação bandada e enclaves de anfibolitos. (b) Microfotografia mostrando duas diferentes populações de zircao encontradas no tonalito gnaisses de Bom Jesus. 1= Ígneo; M= metamorflco. Aumento de 10 vezes no tamanho dos zircões. ( c) Diagrama Concordia para o tonalito gnaisse da regiao de Bom Jesus. Todos os zircoes definem uma idade de cristalização de 3.45 Ga. Estimativa de diferentes idades que podem ser calculadas sao tambem mostradas na figura (ver texto para detalhes). (d) Diagrama Concordia para os zircoes metamorficos. (e) Interpretação de uma historia evolutiva em dois estagios proposta para explicar os zircoes presentes nos gnaisses arqueanos da regiao de Bom Jesus, considerando um evento metamorflco Transamazonico e posterior retrabalhamento durante um evento termal Brasiliano. 


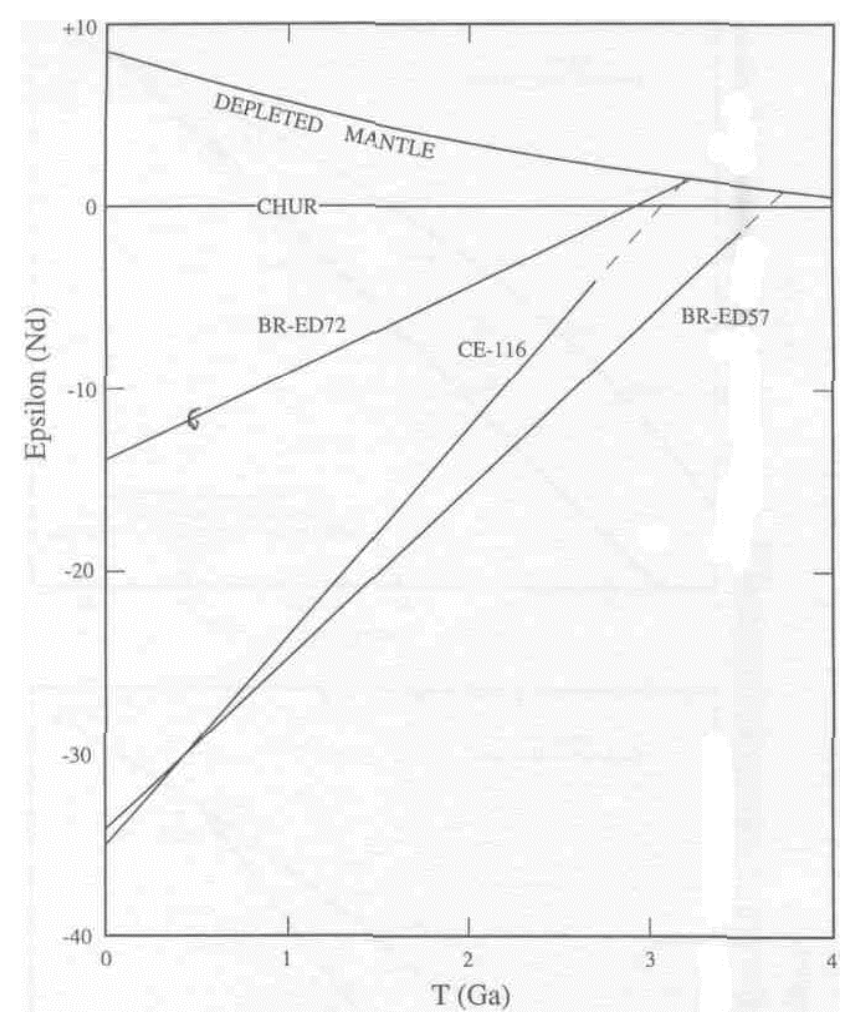

Figure 3. Nd evolution diagram for the three Archean rocks of the Sao José do Campestre Massif dated in this study. Each rock shows different $T_{D M}$ model ages (relative to the depleted mantle evolution curve of DePaolo,1981) and values of eNd (t).

Figura 3. Diagrama de evolução do Nd para as rochas Arqueanas do Maciço Sao José do Campestre. Cada rochas mostra diferente idades modelos TDM e valores de Epsilon $\mathrm{Nd}(0)$ e Epsilon $\mathrm{Nd}(\mathrm{t})$ relative a curva de evolufao do manto empobrecido de DePaolo (1981) e valores de $\mathrm{e}_{\mathrm{Nd}}(\mathrm{t})$.

Trondhjemite Gneiss of Fontes Sample BRED-72 is a highly migmatized, grey, garnet-bearing, trondhjemitic gneiss that was collected in the region known as Fontes, near the town of Brejinho ( $35 \mathrm{~km} \mathrm{SW}$ of Natal, Fig. 1). Three fractions of elongate, uncolored, euhedral zircons were analysed (Table 1), and they define a discordia with intercepts at $3178 \pm 8 \mathrm{Ma}$ and $1154 \pm 104 \mathrm{Ma}$ (Fig. 4). The age of $3178 \mathrm{Ma}$ defined by the upper intercept is interpreted as the crystallization age for the protolith of this rock. The lower intercept at $1154 \mathrm{Ma}$ is interpreted as an apparent age resulting from continuous $\mathrm{Pb}$ loss and has no known geological significance. This sample gives a Sm/Nd TDM model age (DePaolo, 1981) of $3.22 \mathrm{Ga}$, with a positive $\mathrm{e}_{\mathrm{N}} \mathrm{d}(0$ of 1.22 at $3.18 \mathrm{Ga}$ (Table 2 and Fig. 3). We suggest that rocks at this locality represent a phase of Mesoarchean juvenile crust formation at about 3200 Ma.

Syenogranite of Sao Jose do Campestre A small, deformed pluton of syenogranite (sample CE-116) crops out in the Sao Jose do Campestre region (Fig. 1). Six fractions of air-abraded zircons were analysed; they represent two distinct populations: elongate, clear, euhedral grains and light yellow, flat, stubby grains. All analyses fall on the same discordia, with most plotting near the upper intercept (Fig.5). This discordia has intercepts at $2655 \pm 9 \mathrm{Ma}$ and $666 \pm 81 \mathrm{Ma}$, defining a Neoarchean crystallization age for this unit. Although the lower intercept age is close to that of the $600 \mathrm{Ma}$ Brasiliano orogeny, we do not ascribe any geologic signifi-
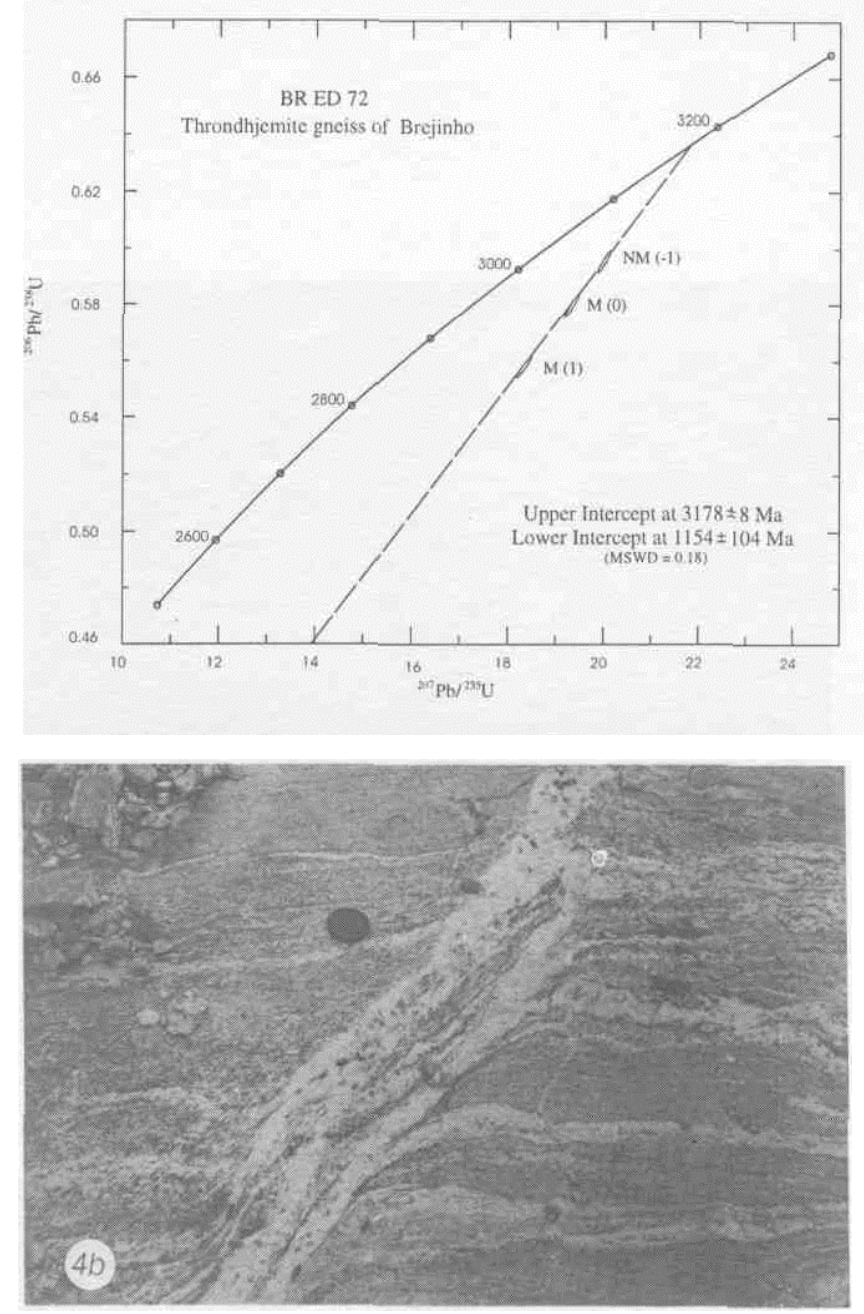

Figure 4. (a) Concordia diagram for garnet-bearing trondhjemite gneiss of Brejinho region, which three zircons fractions of different susceptibility defining a 3.18 Ga crystallization age. (b) Field aspect of the dated trondhjemite gneiss. Figura 4. Diagrama concordia para os trondhjemitos com granada da regiao de Brejinho, cujas 3 frações de zircões com diferentes suceptibilidade, defmem uma idade de cristalizacao em torno de 3.18 Ga. b) Aspecto de campo do trondhjemito gnaisse datado.

cance to it (in part because other samples in the region, discussed above, have distinctly older lower intercept ages). This syenogranite gives a TDM model age of $3.18 \mathrm{Ga}$, with $\mathrm{e}_{\mathrm{Nd}}(\mathrm{t})=-4.2$ at $2690 \mathrm{Ma}$ (Table 2, Fig. 3). This indicates that parental magma for this pluton was probably generated by remelting of Mesoarchean crust about 2700 Ma. This 2700 $\mathrm{Ma}$ age represents the youngest Archean event of the region, an event which includes plutonism and high grade metamorphism. Similar events have been identified in some other areas of the Borborema Province basement and have been widely reported throughout the southern cratonic province (i.e., the São Francisco Craton, Teixeira, 1993).

DISCUSSION AND CONCLUSIONS New U/Pb and $\mathrm{Sm} / \mathrm{Nd}$ geochronological data reveal a suite of rock assemblages previously unreported in the SJCM, a unit in the Borborema Province that has not previously been studied in detail. These assemblages comprise an Archean nucleus that exists within the SJCM as a distinct crustal block surrounded by Paleoproterozoic terranes that comprises the majority of the basement rocks in the Borborema Province. Regional 

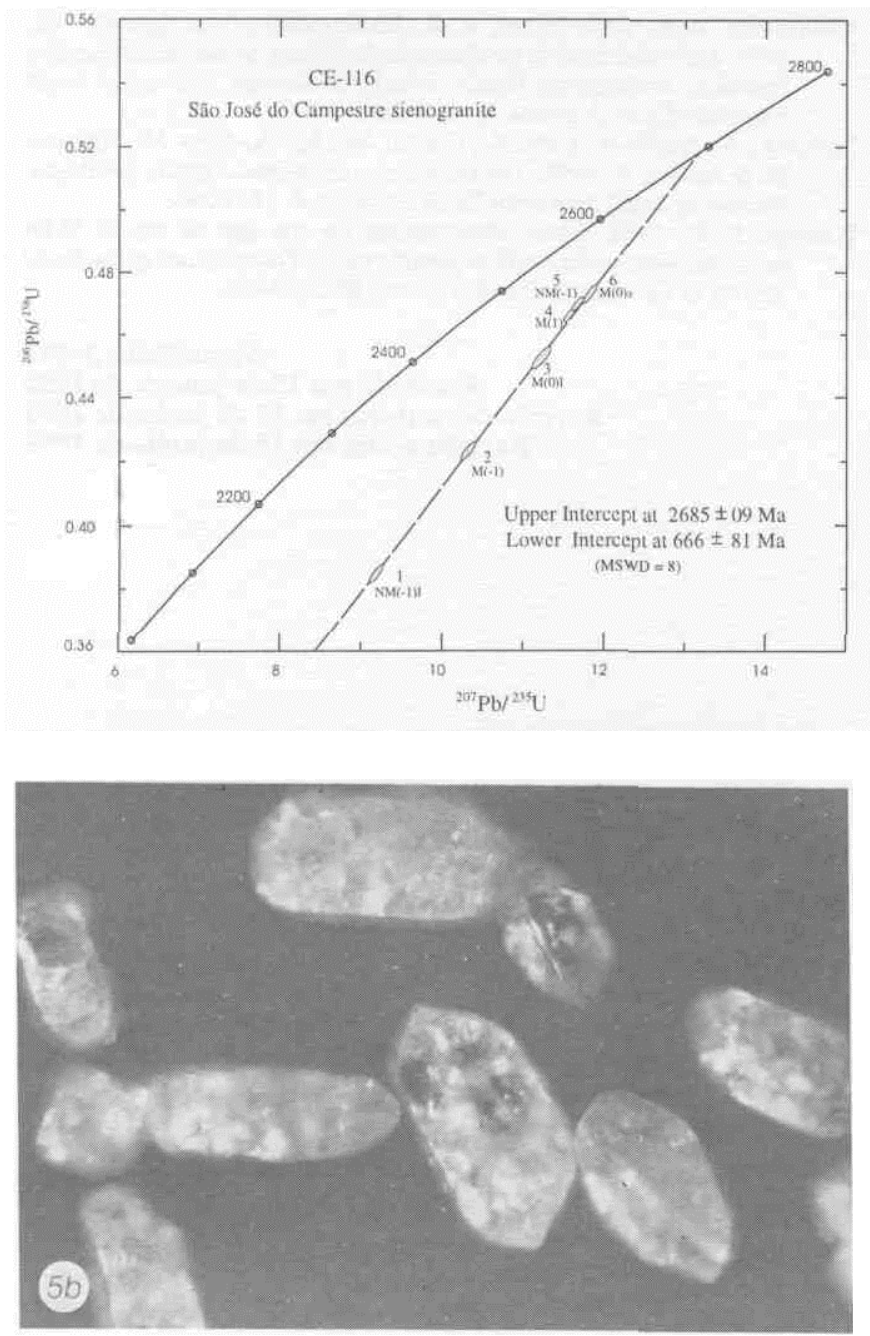

Figura 5. (a) Concordia diagram of coarse texture sienogranite from São José Campestre region showing five fractions that yields a 2.7 Ga crystallization age. (b) Microphotography of zircons founded at sienogranite showing two different morphologies.

Figura 5. Diagrama concordia de um sienogranito grosseiro da regiao de Sao Jose de Campestre, mostrando 5 frafoes que definem uma idade de cristalização de $2.7 \mathrm{Ga}$. b) Microfotografia dos zircões encontrados no sienogranito, em que diferentes morfologias dos graos são mostradas. tectonic and geochronologic studies indicate that this block of Archean crust was subsequently incorporated into Transamazonian mobile belts (ca. 2.1 Ga). These belts were later segmented and reworked during the Neoproterozoic Brasiliano Orogeny.

The U-Pb and Sm-Nd results presented in this paper for the Archean nucleus of the SJCM allow several conclusions that can contribute to better understaning of the geological evolution of the Borborema Province:

1. Earlier $\mathrm{Rb}-\mathrm{Sr}$ geochronology was able to establish the presence of an older Archean crustal component in the SJCM, suggesting an age of $2.7 \mathrm{Ga}$. However, our new U-Pb and Sm-Nd geochronology define a more accurate and more precise stratigraphy for assemblages of rocks in the Archean block that are older than $3.0 \mathrm{Ga}$.

2. Three different periods of magmatism, at 3.4, 3.2, and $2.7 \mathrm{Ga}$, were recorded by the U-Pb system. The Sm-Nd data show two different periods of juvenile crust generation during the Archean evolution of this crustal segment (at ca. 3.2 and 3.4-3.7 Ga) and one younger episode of remelting older crust $(2.7 \mathrm{Ga})$. The two older magmatic phases represent different episodes of accretion of continental crust to an older nucleus; the tectonic setting for the younger event is not yet known. The TDM model ages also show that heterogeneity of source magmas and contributions of reworked and juvenile crust were important during the Archean evolution of SJCM.

3. The Archean nucleus in the SJCM is composed predominantly of grey gneiss and migmatitic rocks, characterizing an assemblage of tonalite-trondhjemite-granodirite rocks (aTTG suite). At least, two generations of trondhjemites occur in SJCM.

4. These results revel an important new crustal segment in the Borborema Province, on which includes some of the oldest rocks known from the Borborema Province in particular and the South American shield in general.

Acknowledgements Elton Dantas was funded by a CNPq PhD thesis grant (201226/93-6), and the work of Hackspacher and Brito Neves was supported by FAPESP (91/01227) and CNPq (522386/95). Van Schmus acknowledges financial support from NSF Grants EAR 9117594, 9345678, and 9614473. We thank Harold G. Fowler for review of the text.

\section{REFERENCES}

Almeida, F. F. M.; Hasui, Y., Brito Neves, B. B. \& Fuck, R.A., 1977, Provmcias estruturais Brasileiras. Atas VIII Simp. Geol. Nordeste, 363-391.

Brito Neves, B. B., 1975, Regionalizacdo geotectonica do Pre-cambriano nordestino. Tese de Doutoramento. IG-USP, 198p.

Brito Neves, B. B., 1983, O mapa geologico do nordeste oriental do Brasil, na escala 1: 1000000 , Tese de livre docencia, IG-USP, 177p.

Corfu, F., 1996, Multistage zircon and titanite growth and inheritance in an Archean gneiss complex, Winnipeg River Subprovince Ontario. Earth Planetary Science Letter, 141: 175-186.

Dantas, E. L.; Cordani, U.; Van Schmus, W. R.; Hackspacher, P. C.; Brito Neves, B. B. \& Nutman, A. P. 1995-Terrenos Arqueanos Paleoproterozoicos do Macifo Caldas Brandao na Provincia Borborema. XVI Simposio de Geologia do Nordeste; Boletim 14 :319-342.

DePaolo, D. J., 1981, A neodymium and strontium isotopic study of the Mesozoic calc-alkaline granitic batholithys of the Sierra Nevada and Peninsular Ranges, California. Journal of Geophysical Research, 86: 10470-10488.
Gebauer, D. \& Grunenfelder, M., 1979, U-Th-Pb dating of minerals. In Jager, E. \& Hunziker, J. C.(Eds), Lectures in Isotope Geology. Springer Verlag; 103-131.

Jardim de Sa, E. F., 1994, A Faixa Seridó (Provincia Borborema, NE Brasil) e o seu significado geodinamico na cadeia Brasiliana/Pan-Africana, Tese de Doutoramento, Univ. Brasilia, 803p.

Krogh, T. E., 1973, A low contamination method for hydrotermal decomposition of zircon and extraction of $\mathrm{U}$ and $\mathrm{Pb}$ for isotopic age determinations. Geochimica et Cosmochimica Acta, 37 : 485-494.

Krogh, T. E., 1982, Improved accuracy of U-Pb zircon ages by the creation of more concordant systems using an air abrasion technique. Geochimica et .Cosmochimica. Acta, 46 : 637-649.

Ludwing, K.R., 1993, ISOPLOT-,4 plotting and regression program for radiogenic isotope data. Version 2.70. June 9, 1993 revision of U.S. Geological Survey Open File Report 91-445, 42p.

Mezger, K. \& Krogstad, J., 1997, Interpretation of discordant U-Pb in zircon ages: An evaluation . J. Metamorphic Geology. 15 : 127-140. 
Parrish, R.R., 1987, An improved micro-capsule for zircon dissolution in U-Pb geochronology. Isotope Geoscience, 66 : 99-102.

Patchett, P. J., \& Ruiz, J.,1987, Nd isotope ages of crust formation and metamorphism in the Precambrian of eastern and southern Mexico. Contribuitions to Mineralogy and Petrology, 96 : 523-528.

Stacey, J.S. \& Kramers, J.D., 1975, Approximation of terrestrial lead isotope evolution by a two stage model: Earth and Planetary Science Letters, $.26,: 207-221$

Steiger, R. H., \& Jager, E., 1977, Subcommission on Geochronologyconvention and use of decay constants in geochronology and cosmochronology: Earth and Planetary Science Letters, 36;: . 359-362.

Teixeira, W., 1993, Avaliacao do aceryo de dados geocronologicos e isotdpicos do Craton Sao Francisco-implica9oes tectonicas. O Craton do Sao Francisco. Domingues, J.M. L \& Misi, A . (Eds.) SBG: SON: CNPq., 11-34.

Toteau, S. F., Macandierre, J.; Betrand, J. M. \& Dautel, D. 1990. Metamorphic zircons from North Cameroom : Implications for the Pan-African evolution of Central Africa, Geologische Rundschau, 79 :777-788.
VanSchmus, W.R., Brito Neves, B. B., Hackspaeher, P. \& Babinski, M., 1995, U-Pb and Sm/Nd geochronologic studies of eastern Borborema Province, northeastern Brazil: initial conclusions. Journal of South American Earth Sciences, 8,: 267-288.

Vauchez, A.; Nevez, S.; Caby, R.; Corsini, M.; Egydio-Silva, M.; Arthaud, M. \& Amaro, V., 1995, The Borborema shear zone system, NE Brazil. Journal of South American Earth Sciences, 8,: 247-266.

Willians, I. S., 1992, Some observations on the use of zircon U-Pb geochronology in the study of granitic rocks. Transactions of the Royal Society of Edinburgh: Earth Sciences, 83 : 447-458.

Manuscrito A-992

Recebido em 15 de Janeiro de 1998 Revisao dos autores em 15 de junho de 1998 Revisao aceita em 15 de junho de 1998 